\title{
「循環器の画像診断 一その現況と将来展望一」
}

\section{体表面心電分布図法}

山形大学第一内科

$$
\text { 久保田 }
$$

功
体表面心電図マッピングとは，胸壁上の広い 領域から多数 (数十 数百) の単極誘導心電図 を記録する方法であり，体表面上で得られる心 電図情報を最大限に利用して心疾患の評価を行 う目的で施行される。本法は臨床的に，虚血性 心疾患の診断, 左室肥大 - 右室肥大の診断, 心 室内伝導障害部位の診断, WPW 症候群の副伝 導路部位の推定, 心室性不整脈の発生部位の診 断あるいは重症心室性不整脈の発生し易さの評 価などの目的で行われている.

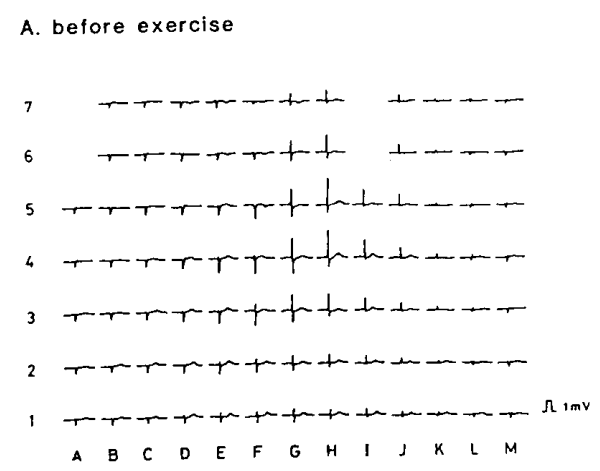

B. after exercise

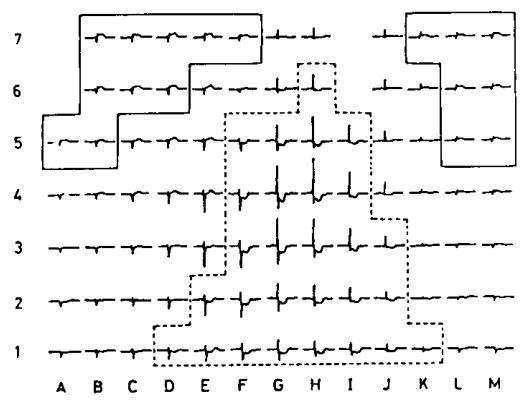

図 1 三枝病変を有する一症例のトレッドミ ル負荷前 (A) および負荷後 (B) の 全87誘導心電図波形, ST 低下領域を 破線で，ST 上昇領域を実線で囲んだ.
ここでは，我々の教室において施行している 運動負荷体表面心電図マッピングによる心筋虚 血の診断について述べる. 対象は, 心䈘梗塞の 既往がなく，冠動脈造影にて70\%以上の狭窄が 確認されている虚血性心疾患患者である．体表 面心電図マッピングは，山田らの方法に従い， HPM - 5100 あるいは VCM-3000 装置を用 いて, 胸壁上の87点からトレッドミル運動負荷 前および後に行った。

狭心症患者の運動負荷後に生ずる虚血型 ST

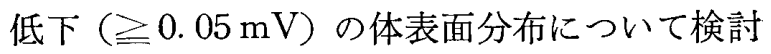
した. 図 1 に症例を示す。上段(A)が負荷前，下 段(B)が負荷後の心電図波形である．A，E，I 列 が, それぞれ右腋窩中線, 胸骨正中線, 左腋窝 中線の誘導点であり, 第 6,4 行がそれぞれ, 胸 骨正中線上で第 2,5 肋間の高さにある. 負荷 前にはいずれの誘導にもST の低下は認められ

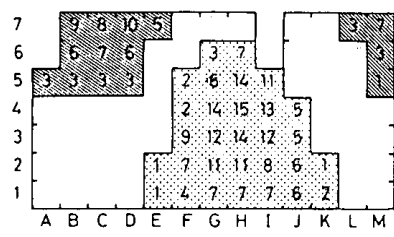

$\operatorname{LAD}(n=19)$

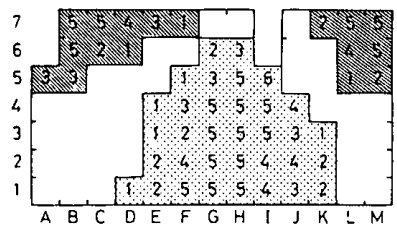

$\operatorname{LCX}(n=6)$

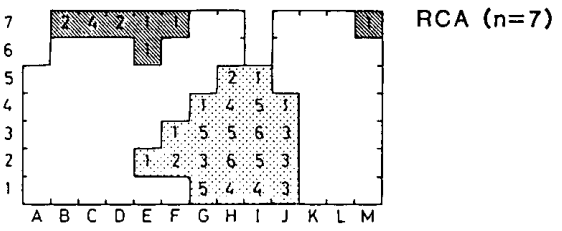

図 2 一枝病変群における ST 変化の体表面分布 
Type A
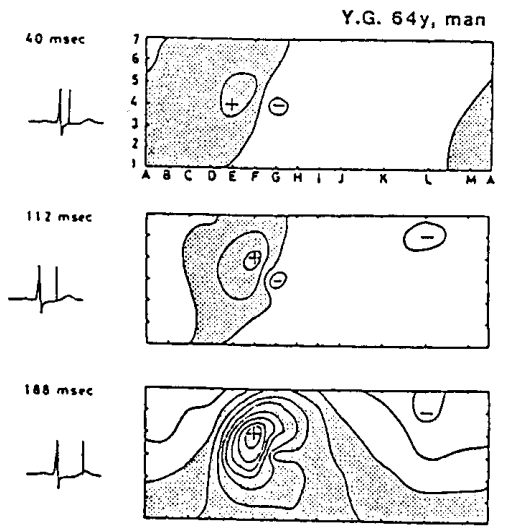

- $260 \mathrm{msec}$
Type B
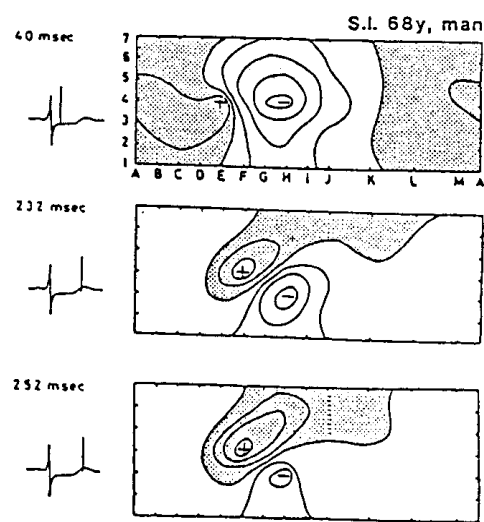

-

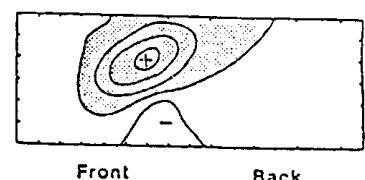

Type C
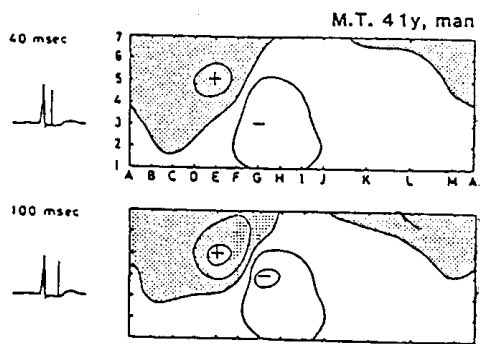

$120 \mathrm{mses}$
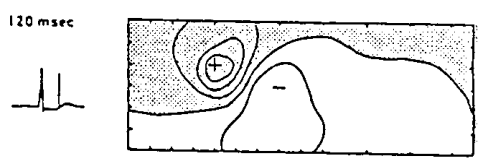

200 msec

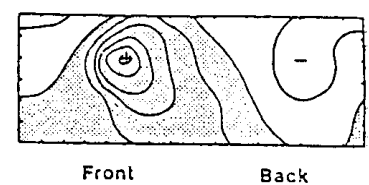

図 3 運動負荷後の $\mathbf{S T}-\mathbf{T}$ 部の等電位図の分類

ないが，負荷後に左前胸部を中心とした点線で 囲んだ領域で虚血型 ST 低下の出現をみた。こ こで，ST の低下を示した誘導数と，運動負荷 ${ }^{201} \mathrm{Tl}$ 心筋シンチグラムより求めた mean washout rate との関係を各症例毎に調べると，良好 な負の相関が認められた，従って，体表面上の 運動負荷後の ST 低下領域の広さは, 心筋虚血 の重症度を反映すると考えられた。

一枝病変患者の負荷後の ST 変化の体表面分 布を図 2 に示す. ST低下領域を点で，ST上昇 領域を斜線で覆った. 図中の数字法, 各誘導点 において ST 変化 (ミ0.05 mV) を示した症例 数を示す. 右冠動脈群は, 左前下行枝群に比較 して，やや下方の誘導で ST 低下を多く認める 傾向があった. しかし, 各一枝病変群の ST 低 下領域の間にはかなりの程度の重なり合いが認 められた．ST 低下を示す誘導部位から罹患動 脈を推定することは困難であると考えられた。

安静時心電図で $\mathrm{ST}-\mathrm{T}$ 異常がなく, 運動負 荷にて虚血型 ST 低下 $(\geqq 0.1 \mathrm{mV})$ を認める 一枝病変の労作狭心症 21 名を対象とし, 負荷後 の $\mathrm{ST}-\mathrm{T}$ 部等電位図の有する診断的意義につ いて検討した，等電位図とは，ある瞬時におけ る体表面上の電位分布を等電位線で表現した図 であり，J点から $40 \mathrm{msec}$ 後から T波終末まで $4 \mathrm{msec}$ 間隔で作成した。負荷後の ST 部（J 点より $40 \mathrm{msec}$ 後) の等電位図では，全例左前
胸部に極小が認められ，再分極の進行に伴うこ の極小の位置変化から, 等電位図を 4 型に分類 した(図3). 図3において，等電位線は $0.1 \mathrm{mV}$ 間隔で描き，正電位領域を灰色で示したＡ型 （8名）は新たな優勢な極小が出現する時期ま で，前胸部に極小が停滞するもの，B型( 6 名) は極小が徐々に前胸壁下方へ移動するもの，C 型（5 名）は極小が徐々に左上方から背部へと 移動するものであり，分類不能な 2 名をD型と した，A型，B型，C型を示した症例はそれぞ れ全例, 左前下行枝, 右冠動脈, 左回旋枝病変 を有していた. 運動負荷後の ST - T 部の等電 位図は，罹患動脈の推定に有用であることが示 唆された。

\section{1) upper type}

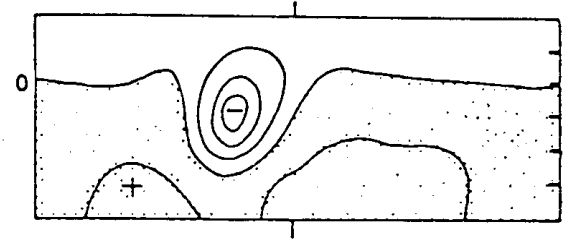

2) lower type

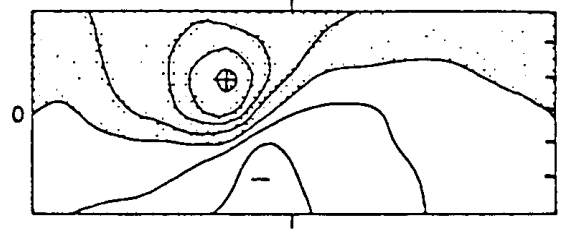

図 4 運動負荷後に出現した陰性U 波の 等電位図 
54yrs. M LAD disease

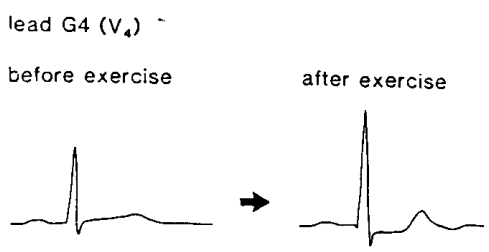

R difference map $(\Delta R)$

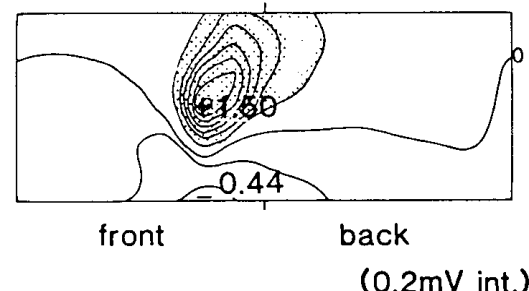

isochrone map (VAT)

before exercise

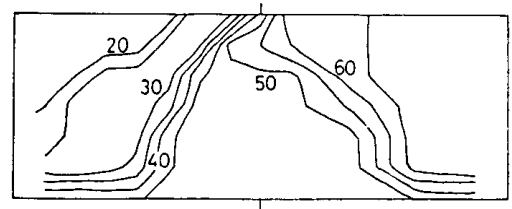

after exercise

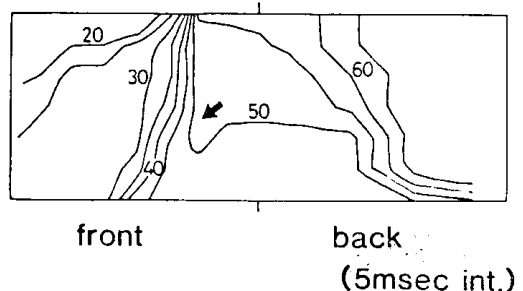

図 5 運動負荷後に左前胸部で $R$ 波の著明な増高と等時線の晕延を生じた狭心症の 1 例

負荷後の陰性 U 波の体表面分布について検 討した. 陰性U波の出現領域から upper type, lower type（図 4) に分類し，運動負荷 ${ }^{201} \mathrm{Tl}$ 心 筋シンチグラム所見と対比した. upper type は 左室前壁の, lower type は左室後壁の一過性欠 損との対応が認められた．陰性U波は，必ずし もその出現率は高くないが，出現した場合には その体表面分布から心筋虚血部の誘断に有用で あると考えられた。

図 5 に負荷後に左前胸部を中心として著明な $\mathrm{R}$ 波増高を生じ， R 波増高領域で等時線の遅延 を生じた症例を示す，等時線とは，心室興奮開 始から各誘導点毎に R 波の頂点あるいは $-\mathrm{dV} /$ $\mathrm{dt}(\mathrm{V}$ : 電位) が最大となるときまでの時間を VAT とし，VAT の体表面分布を表す図であ
る. 我々は, 負荷後の VAT の遅延領域により 心筋虚血部位が推定できるのではと考えている.

以上，運動負荷体表面心電図マッピングによ る心筋虚血の診断について解説した．ST 低下 の体表面分布から心筋虚血の重症度を評価する ことができるが，心筋虚血部位の診断を行うの は困難と考えられた．ST 低下にT波・陰性U 波の等電位図あるいは等時線図など検討するこ とにより，心筋虚血部位の診断も可能になると 考えられた。このように，体表面心電分布図法 は，心電現象を空間的に把え，種々の図として 表現することにより，従来の心電図法では得る ことのできなかった心電図情報を提供すること ができる. 